\title{
KODE ETIK PROFESI KONSELING SERTA PERMASALAHAN DALAM PENERAPANNYA
}

\author{
Eko Sujadi \\ Institut Agama Islam Negeri (LAIN) Kerinci \\ e-mail: ekosujadi91@gmail.com
}

\begin{abstract}
Every individual is required to be able to adjust to changes that occur. For individuals who are not able to adjust to the changes, it can cause problems for them. This conditions provides great opportunities for counselors to organize counseling services. Counselors are supposedly able to apply the code of conduct in providing services to clients. Various issues of implementing the code of conduct are occurring in the implementation of counseling services, whether it is caused by counselor or external parties. Therefore, counselor should cultivate self-awareness to carry out a duty correctly, continue to improve the competence, as well as policy makers should formulate clear regulations and properly accompanied by supervision.
\end{abstract}

Keyword: Code of ethics, Guidance and Counseling, Problems

\begin{abstract}
Abstrak: Abstrak. Setiap individu dituntut mampu menyesuaikan diri dengan perubahan yang terjadi. Bagi individu yang tidak mampu menyesuaikan diri dengan perubahan, maka dapat menimbulkan masalah baginya. Kondisi ini memberikan peluang yang besar bagi konselor untuk menyelenggarakan pelayanan konseling kepada individu-individu yang bermasalah. Dalam memberikan layanan kepada klien, konselor harus menegakkan kode etik. Berbagai masalah dalam penerapan kode etik terjadi dalam pelaksanaan layanan konseling, baik yang disebabkan oleh konselor itu sendiri atau pihak eksternal. Oleh sebab itu, konselor harus memiliki kesadaran yang tinggi untuk melaksanakan tugas dengan benar, terus meningkatkan kompetensi, serta bagi pembuat kebijakan untuk merumuskan peraturan yang jelas disertai dengan pengawasan.
\end{abstract}

Kata Kunci: Kode Etik, Bimbingan dan Konseling, Permasalahan 


\section{PENDAHULUAN}

Perubahan sosial yang begitu cepat (rapid social change) secara jelas telah mempengaruhi gaya hidup masyarakat. Mereka dituntut untuk dapat menyesuaikan diri dengan perubahanperubahan tersebut sehingga tidak menimbulkan beragam permasalahan. Kompleksitas permasalahan tersebut hendaknya juga diikuti dengan daya tahan dari individu itu sendiri, baik dari segi fisik maupun psikologis.

Tentunya fenomena ini memberikan peluang kepada profesi konselor agar dapat menunjukkan "taringnya". Oleh sebab itu, sudah seharusnya Konselor memiliki wawasan, pengetahuan, keterampilan, nilai dan sikap yang memadai dalam melaksanakan konseling untuk semua jenis keberagaman tersebut.

Konselor hendaknya sadar bahwa klien datang dengan membawa harapan bahwa ia adalah sosok yang dapat membantu dalam menyelesaikan permasalahan. Oleh sebab itu, penerimaan Konselor yang hangat dan terbuka kepada klien akan memberikan warna positif bagi terlaksananya konseling yang efektif. Konselor juga harus menyadari bahwa ia tidak boleh memaksakan nilai-nilai yang dianutnya kepada klien ataupun bertindak tanpa adanya aturanaturan yang mengikat.

Walaupun demikian, ternyata tidak sedikit juga pengguna pelayanan konseling yang memiliki persepsi negatif terhadap profesi konselor, yang sebenarnya bersumber dari kesalahankesalahan oknum konselor itu sendiri. Seperti kurangnya kepercayaan siswa untuk konseling kepada guru BK di sekolah dengan alasan khawatir rahasianya akan terbongkar, bahkan ada guru BK/Konselor sekolah yang melaksanakan malpraktik pelayanan konseling.

Dengan melihat gejala-gejala tersebut, Konselor dalam melaksanakan tugasnya, selain dituntut memiliki kompetensi profesional juga harus diiringi oleh serangkaian etika. Oleh sebab itu, ABKIN selaku organisasi induk Bimbingan dan Konseling di tanah air menyusun serangkaian kode etik profesi bimbingan konseling yang harus diikuti oleh semua konselor yang melaksanakan praktik konseling baik di sekolah maupun di luar sekolah.

\section{PEMBAHASAN}

\section{Kode Etik Profesi Konselor}

Konseling merupakan proses pelayanan bantuan yang pelaksanaannya didasarkan atas keahlian. Dengan demikian, dapat dipahami bahwa konseling tidak bisa dilaksanakan secara asalasalan, namun harus ada keterampilan khusus yang dimiliki konselor. Keterampilan tersebut tidak terbatas hanya pada kompetensi profesional, dalam artian bagaimana konselor mampu 
memahami teoritis pelayanan konseling dan menerapkannya, namun lebih luas seorang konselor harus memenuhi dirinya dengan kompetensi pribadi, sosial, dan pedagogik.

Berdasarkan karakteristik seperti yang telah dikemukakan di atas, maka setiap praktisi bimbingan dan konseling dalam melaksanakan tugasnya harus diiringi etika-etika khusus. Etika dalam proses konseling disusun dalam bentuk kode etik profesi sehingga mudah dipahami, dihayati, dan dilaksanakan oleh konselor. Menurut Sunaryo Kartadinata (2011:15) kode etik profesi adalah regulasi dan norma perilaku profesional yang harus diindahkan oleh setiap anggota profesi dalam menjalankan tugas profesi dan dalam kehidupannya di dalam masyarakat. Menurut Abkin (2006:94) kode etik merupakan suatu aturan yang melindungi profesi dari campur tangan pemerintah, mencegah ketidaksepakatan internal dalam suatu profesi, dan melindungi atau mencegah para praktisi dari perilaku-perilaku malpraktik. Selanjutnya Abkin (2006:92) mengemukakan bahwa kekuatan dan eksistensi suatu profesi muncul dari kepercayaan publik. Etika konseling harus melibatkan kesadaran dan komitmen untuk memelihara pentingnya tanggungjawab melindungi kepercayaan klien.

Abkin (2006:94) mengemukakan bahwa penegasan identitas profesi Bimbingan dan Konseling harus diwujudkan dalam implementasi kode etik dan supervisinya. Sunaryo Kartadinata (2011:15) menjelaskan bahwa penegakan dan penerapan kode etik bertujuan untuk: (1) menjunjung tinggi martabat profesi; (2) melindungi masyarakat dari perbuatan malpraktik; (3) meningkatkan mutu profesi; (5) menjaga standar mutu dan status profesi, dan (6) penegakan ikatan antara tenaga profesi dan profesi yang disandangnya.

Kode Etik Bimbingan dan Konseling di Indonesia sebagaimana disusun oleh ABKIN (2006:69) memuat hal-hal berikut:

1. Kualifikasi; bahwa konselor wajib memiliki a) nilai, sikap, keterampilan, pengetahuan dan wawasan dalam bidang Bimbingan dan Konseling, b) memperoleh pengakuan atas kemampuan dan kewenangan sebagai Konselor.

2. Informasi, testing dan riset; a) penyimpanan dan penggunaan informasi, b) testing, diberikan kepada Konselor yang berwenang menggunakan dan menafsirkan hasilnya, c) riset, menjaga prinsip-prinisp sasaran riset serta kerahasiaan.

3. Proses pada pelayanan; a) hubungan dalam pemberian pada pelayanan, b) hubungan dengan klien.

4. Konsultasi dan hubungan dengan rekan sejawat atau ahli lain; a) pentingnya berkonsultasi dengan sesama rekan sejawat; b) alih tangan kasus apabila tidak dapat memberikan bantuan kepada klien tersebut. 
5. Hubungan kelembagaan; memuat mengenai aturan pelaksanaan layanan konseling yang berhubungan dengan kelembagaan

6. Praktik mandiri dan laporan kepada pihak lain; 1) konselor praktik mandiri, menyangkut aturan dalam melaksanakan konseling secara private, 2) laporan kepada pihak lain.

7. Ketaatan kepada profesi, 1) pelaksanaan hak dan kewajiban, serta 2) pelanggaran terhadap kode etik.

Selanjutnya Uman Suherman (2007) menegaskan bahwa seorang konselor hendaknya menunjukkan sikap dan perilaku sebagai berikut: (1) berusaha meciptakan suasana dan hubungan konseling yang kondusif; (2) berusaha menjaga sikap objektif terhadap klien; (3) mengekplorasi faktor penyebab masalah-masalah psikologis, baik masa lalu maupun masa kini; (4) menentukan kerangka rujukan atau perangkat kognitif terhadap kesulitan klien dengan cara yang dapat dimengerti klien; (5) konseling memiliki strategi untuk mengubah kembali perilaku salah suai, keyakinan irasional, gangguan emosi dan menyalahkan diri sendiri; (6) mempertahankan transfer pemahaman tentang perilaku baru yang diperlukan klien dalam kehidupan sehari-harinya; (7) menjadi model atau contoh sosok yang memiliki sikap sehat dan normal; (8) menyadari kesalahan yang pernah dibuat dan resiko yang dihadapi; (9) dapat dipercaya dan mampu menjaga kerahasiaan; (10) memiliki orientasi diri yang selalu berkembang; dan (11) ikhlas dalam menjalankan profesinya.

Berdasarkan pemaparan di atas, maka dapat dipahami bahwa seorang konselor tidak hanya dituntut secara teknis menguasai keseluruhan aspek teoritis dan praktis Bimbingan dan Konseling, namun juga harus memiliki segenap aspek kepribadian yang positif. Setiap pelanggaran terhadap kode etik dapat menyebabkan kerugian bagi diri konselor sendiri maupun pihak yang dilayani. Bahkan Abkin menegaskan bahwa setiap pelanggaran terhadap kode etik akan mendapatkan sanksi berdasarkan ketentuan yang ditetapkan oleh Asosiasi Bimbingan dan Konseling Indonesia (Bab V kode etik Profesi Bimbingan dan Konseling).

\section{Permasalahan dalam Penerapan Kode Etik Profesi Bimbingan dan Konseling}

Kode etik profesi bimbingan dan konseling seperti yang telah dipaparkan di atas belum sepenuhnya terimplementasikan secara baik. Masih banyak terjadi kekeliruan dalam pelaksanakan pelayanan bimbingan dan konseling yang justru dilakukan oleh guru BK/Konselor sekolah itu sendiri. Seperti penelitian yang dilakukan Suhertina (2010) terkait dengan implementasi kode etik bimbingan dan konseling, ditemukan hasil bahwa Guru BK atau konselor sekolah memiliki pemahaman yang relatif rendah terkait dengan kode etik BK, bahkan yang mengejutkan yakni sebagian konselor sekolah tidak mengenal kode etik BK. 
Menurut Yusri (2012) untuk memenuhi standar kualifikasi tenaga pendidik, telah dilakukan beberapa upaya seperti dengan pengembangan diri melalui pendidikan akademis dan profesi serta melakukan ujian kompetensi guru (UKG). Pada kenyataannya, hasil UKG baru mencapai hasil rata-rata 4.5. Melihat realita itu, Yusri (2012) mengajukan pertanyaan 1. Apakah guru bimbingan dan konseling/ Konselor telah melakukan studi kebutuhan untuk menyusun program BK di sekolah?; 2. Apakah guru bimbingan dan konseling/ konselor sudah memahami karakteristik setiap siswa asuhnya?; 3. Apakah guru bimbingan dan konseling/konselor telah memiliki kemampuan untuk mengaplikasikan kompetensinya dalam mencegah dan mengentaskan permasalahan siswa?; 4. Apakah guru bimbingan dan konseling/ konselor telah memiliki komitmen kerja yang baik sesuai dengan janji profesi?

Hartono (2009) juga mengatakan bahwa di sekolah beberapa kali terjadi kebijakan birokrasi yang justru mengaburkan eksistensi dan peran bimbingan dan konseling sebagai layanan ahli, seperti adanya penugasan menjadi guru pembimbing (konselor sekolah) bagi seseorang guru yang tidak memiliki kompetensi bimbingan dan konseling tanpa pendidikan dan pelatihan yang memadai. Padahal berdasarkan kode etik profesi konseling, tercantum secara jelas bahwa seorang guru BK harus memiliki kualifikasi yang memadai yang meliputi nilai, sikap, keterampilan, pengetahuan dan wawasan dalam bidang Bimbingan dan Konseling, serta memperoleh pengakuan atas kemampuan dan kewenangan sebagai Konselor.

Prayitno \& Erman Amti (2004) menjelaskan bahwa masih banyak kesalahpahaman tentang Bimbingan dan Konseling. Salah satu penyebabnya adalah bidang bimbingan dan konseling digeluti oleh pihak yang bukan berlatar belakang dari pendidikan bimbingan dan konseling. Pelaksanaan Bimbingan dan konseling umumnya hanya untuk mengurusi siswa-siswa yang bermasalah, baik yang dipanggil langsung oleh Konselor maupun dirujuk oleh pihak lain, sehingga wajar apabila siswa tidak mau memanfaatkan pelayanan Bimbingan dan Konseling. Mereka memiliki anggapan bahwa apabila apabila datang ke ruangan BK maka menunjukan ia mengalami ketidakberesan tertentu.

Ika Kusuma Wardani dan Retno Tri Hariastuti (2009) melakukan survei sederhana dengan cara menyebarkan angket terbuka kepada siswa dengan hasil bahwa 60\% siswa mempunyai pandangan bahwa konselor sekolah merupakan guru yang galak, suka memarahi dan menghukum siswa yang melanggar tata tertib sekolah, serta terkadang kurang tegas dalam menghadapi siswa. Data juga menunjukkan bahwa polisi sekolah merupakan image yang sering disandang oleh seorang konselor sekolah. Persepsi tersebut tampaknya telah membentuk pikiranpikiran negatif siswa sehingga mempengaruhi pemahaman siswa tentang hakikat keberadaan konselor sekolah. 
Berdasarkan penjelasan di atas terkait dengan permasalahan dalam penerapan kode etik, penulis dapat merumuskan sumber permasalahannya antara lain:

1. Pelaksana pelayanan bimbingan dan konseling yang kurang memiliki kompetensi. Hal ini dikarenakan banyak guru BK yang tidak berlatar belakang pendidikan Bimbingan dan Konseling. Selain itu kemauan guru BK untuk mengembangkan kompetensi seperti mengikuti pelatihan/ seminar/ worskhop atau melanjutkan pendidikan yang linear masih rendah. Implikasi dari rendahnya penguasaan kompetensi tersebut yakni buruknya pelayanan yang diberikan kepada pengguna pelayanan konseling, seperti ada guru BK yang menjadi polisi sekolah, guru BK yang pemarah/galak, guru BK yang tidak mampu menyusun program BK, guru BK yang tidak mampu melakukan kerjasama dengan rekan sejawat, di luar profesi atau hubungan dengan lembaga, ketidakmampuan guru BK dalam menerapkan ilmu pendidikan ketika melaksanakan pelayanan, ketidakmampuan guru BK dalam melakukan evaluasi dan melakukan tindak lanjut dari evaluasi, serta masih banyak lagi.

2. Pihak di luar BK. Bimbingan dan Konseling merupakan bagian dari sistem pendidikan itu sendiri, sehingga bagaimana dukungan dari sistem akan memberikan warna postif pada terlaksananya pelayanan konseling. Namun seperti yang kita lihat bahwa beberapa kebijakan yang dibuat oleh pihak tertentu justru mengaburkan hakikat pelaksanaan layanan bimbingan dan konseling. Hal ini disebabkan kurangnya pengetahuan para pembuat kebijakan mengenai pelaksanaan pelayanan konseling yang ideal. Contohnya seperti yang telah dipaparkan di atas, bahwa ada kebijakan yang dikeluarkan oleh pihak berwenang untuk mengangkat guru mata pelajaran menjadi guru Bimbingan dan Konseling dikarenakan lebihnya guru mata pelajaran. Dapat dibayangkan bagaimana pelaksanaan pelayanan bimbingan dan konseling yang dilaksanakan oleh tenaga yang tidak mengerti mengenai bimbingan dan konseling.

Demikian kompleksnya permasalahan terkait implementasi kode etik profesi Bimbingan dan Konseling, menimbulkan ketidakpercayaan masyarakat untuk memanfaatkan pelayanan konseling. Banyak masyarakat yang masih "kabur" mengenai apa itu konseling, siapa yang memberikan pelayanan konseling, permasalahan apa saja yang dapat ditangani oleh konselor, dan apa saja kompetensi yang harus dimiliki oleh seorang konselor. Persepsi seperti itu justru akan menghambat konseling untuk menjadi profesi yang bermartabat. Kita lihat saja beberapa profesi lain yang telah kokoh menunjukkan eksistensinya, sebut saja profesi Dokter, Advokat, Akuntan, Psikolog, dan masih banyak lagi. Masyakarat akan berbondong-bondong untuk mendatangi profesi-profesi tersebut ketika berhadapan dengan permasalahan-permasalahan tertentu.

Pada hakikatnya untuk menjadikan profesi bimbingan dan konseling lebih bermartabat, di mana kode etik profesi ditegakkan, harus dimulai dari kesadaran pada diri pelaksana pelayanan 
bimbingan dan konseling. Guru BK/Konselor haruslah bersikap idealis dengan melaksanakan tugas pokok dan fungsinya secara benar. Mereka hendaknya menumbuhkan perilaku altruistik, yakni keinginan membantu orang lain untuk menjadi yang lebih baik dibandingkan menuntut haknya.

Konselor hendaknya juga senantiasa meningkatkan kualitas kepribadian. Ciri-ciri kepribadian yang seyogyanya harus dimiliki oleh Konselor menurut Sukartini (2011:17) antara lain: (1) beriman dan bertaqwa kepada Tuhan yang maha esa; (2) berpandangan positif dan dinamis tentang manusia sebagai makhluk spiritual, bermoral, individual dan sosial; (3) menghargai harkat dan martabat manusia dan hak asasinya serta sikap demokrtatis; (4) menampilkan nilai, norma, dan moral yang beraku dan berakhlak mulia; (5) menamplkan integritas dan stabilitas kepribadian dan kematangan emosional;dan (6) cerdas, kreatif, mandiri dan berpenampilan menarik.

Selain itu, instansi terkait juga dapat menyediakan sarana bagi pengembangan kompetensi guru BK/Konselor, seperti mengadakan seminar/ workshop/ diklat dan sejenisnya, di mana setiap guru BK diwajibkan untuk mengikuti kegiatan tersebut. Uman Suherman (2007) merincikan bahwa peningkatan kualitas profesi konselor secara berkelanjutan hendaknya terilhat dalam peningkatan kinerja profesional, penguasaan landasan profesional, penguasaan materi akademik, penguasaan keterampilan proses, penguasaan penyesuaian interaksional, kepribadian, kreatif, dan peningkatan kolaborasi

Apabila kompetensi telah terpenuhi, jika tanpa adanya regulasi yang jelas juga akan menghambat jalannya suatu profesi. Dengan demikian, pembuat kebijakan dapat menyusun regulasi mengenai pelaksanaan bimbingan dan konseling di satuan pendidikan, di mana tujuan dari regulasi tersebut adalah memperkuat keberadaan pelaksanaan pelayanan bimbingan dan konseling itu sendiri, bukan semakin melemahkan atau mengaburkan standar pelaksanaannya. Terkait dengan jam pembelajaran bimbingan dan konseling di satuan pendidikan, spektrum pelayanan konseling, tugas pokok guru bimbingan dan konseling, pengawasan, hingga akuntabilitas pelaksanaan program harus tercantum secara jelas dan operasional di dalam regulasi tersebut. Lebih jauh lagi, isi dari peraturan tersebut adalah mengarah kepada tegaknya kode etik profesi Bimbingan dan Konseling.

Agar kebijakan yang telah dibuat dapat terlaksana dengan baik maka harus disertai pengawasan terhadap kebijakan tersebut beserta sanksi tegas bagi pelanggarnya. Coba kita sejenak merujuk kepada kode etik kedokteran, di mana tidak ada keringanan bagi mereka yang melanggar aturan tersebut karena menyangkut keselamatan manusia. Lantas bagaimana dengan Bimbingan dan Konseling? Bukankah aspek kedirian klien dengan dinamikanya tersendiri juga merupakan hal 
penting yang hendaknya dijunjung, agak setiap individu dapat menjadi manusia yang berharkat dan bermartabat?

\section{PENUTUP}

Penerapan kode etik profesi bimbingan dan konseling di Indonesia masih belum tercapai secara maksimal. Masih banyak guru BK/Konselor yang tidak mengetahui rincian kode etik profesi serta tidak mampu melaksanakannya. Selain itu, pihak luar juga memiliki andil pada terhambatnya penerapan kode etik profesi bimbingan dan konseling. Permasalahan tersebut tentunya harus segera dapat diatasi. Langkah pertama yang harus dilakukan yakni menumbuhkan kesadaran pada diri masing-masing guru BK/Konselor bahwa mereka harus senantiasa menjalankan tugas pokoknya secara benar, mereka juga secara berkesinambunan harus mengembangkan diri baik secara formal maupun berdiskusi dengan rekan sejawat. Bagi para pembuat kebijakan, hendaknya dapat menyusun regulasi yang jelas dan benar disertai dengan petunjuk teknis pelaksanaannya. Pelaksanaan regulasi tersebut seharusnya senantiasa diawasi baik dalam proses pelaksanaanya maupun pasca pelaksanaan pelayanan.

\section{REFERENSI}

AS, Uman Suherman. (2007). "Kompetensi dan Aspek Etik Profesional Konselor Masa Depan". Educationist, 1 (1): 39-47.

Hartono. (2009). "Efektivitas Bimbingan Karier Berbantuan Komputer Terhadap Kemandirian Pengambilan Keputusan Karier Siswa SMA”. Jurnal PPB UNNESA, 10 (1).

Hayati, I., \& Sujadi, E. (2018). Perbedaan Keterampilan Belajar Antara Siswa IPA dan IPS. Tarbawi : Jurnal Ilmu Pendidikan, 14(1), 1-10

Pengurus Daerah ABKIN Jawa Tengah. (2006). Asosiasi Bimbingan dan Konseling Indonesia. Jawa Tengah

Prayitno \& Amti, Erman. (2004). Dasar-dasar Bimbingan dan Konseling. Jakarta: PT Rineka Cipta.

Suhertina. (2012). "Peningkatan Profesionalisme Konselor Melalui Implementasi Kode Etik Bimbingan Konseling di Sekolah". Artikel disajikan dalam Seminar Internasional Konseling Malindo-2, Jurusan BK UNP, Padang, 13-15 November.

Sukartini, S.P. (2011). "Pribadi Konselor"; dalam Mamat Supriatna. (Ed), Bimbingan dan Konseling Berbasis Kompetensi (Orientasi Dasar Pengembangan Profesi Konselor). Jakarta: Rajawali Pers.

Wardani, Ika Kusuma \& Hariastuti, Retno Tri. (2009). "Mengurangi Persepsi Negatif Siswa Tentang Konselor Sekolah dengan Strategi Pengubahan Pola Pikir (Cognitive Restructuring)". Jurnal PPB UNNESA, 10 (2). 
Yusri. (2012). "Meningkatkan Kinerja Guru Bimbingan dan Konseling/Konselor Profesional di Sekolah". Artikel disajikan dalam Seminar Internasional Konseling Malindo-2, Jurusan BK UNP, Padang, 13-15 November. 